\title{
Resistance to Bemisia tabaci in tomato wild relatives
}

\author{
Syarifin Firdaus • Adriaan W. van Heusden • \\ Nurul Hidayati • Ence Darmo Jaya Supena • \\ Richard G. F. Visser · Ben Vosman
}

Received: 18 January 2012/ Accepted: 19 April 2012/Published online: 18 May 2012

(C) The Author(s) 2012. This article is published with open access at Springerlink.com

\begin{abstract}
Bemisia tabaci is one of the most threatening pests in agriculture, particularly in Solanaceous crops such as tomato and pepper that are cultivated in the open field. Pesticide application is often not effective and hazardous to humans and environment. The exploitation of plant natural defenses that are present in wild relatives of tomato, may offer a solution. To evaluate resistance parameters and to identify plant material with high levels of resistance, we screened a number of accessions of tomato wild relatives using three methods; a free-choice test in a screenhouse in
\end{abstract}

Electronic supplementary material The online version of this article (doi:10.1007/s10681-012-0704-2) contains supplementary material, which is available to authorized users.

S. Firdaus - E. D. J. Supena

Research Center for Bioresources and Biotechnology, Bogor Agricultural University, Bogor 16680, West Java, Indonesia

S. Firdaus - A. W. van Heusden ( $\square)$.

R. G. F. Visser · B. Vosman

Department of Plant Breeding, Wageningen University and Research Centre, PO Box 386, 6700 AJ Wageningen, The Netherlands

e-mail: sjaak.vanheusden@wur.nl

S. Firdaus

Graduate School Experimental Plant Sciences,

Wageningen, The Netherlands

N. Hidayati

PT East West Seed Indonesia (EWINDO), Purwakarta

41181, West Java, Indonesia
Indonesia, a no-choice test with clip-on cages in a greenhouse and a leaf disc test in a climate-room in the Netherlands. Antibiosis resulting in low adult survival was the major component for resistance in tomato. However, other resistance component(s) may play a role as well. In some accessions there was a change in the resistance level over time. Several resistance parameters used in the different tests were well correlated. The best resistance source was an accession of Solanum galapagense, which had not been identified as being resistant in the past. This is of particular interest as this species is closely related to the cultivated tomato, which may facilitate introgression of the resistance component(s). Whitefly non-preference and resistance were associated with the presence of type IV trichomes. Other mechanisms might be involved since some accessions without type IV trichomes showed low nymphal density. The leaf disc test is a good in vitro alternative for the clip-on cage whitefly resistance screening, as shown by the high correlation between the results obtained with this test and the clip-on cage test. This offers breeders the possibility to carry out tests more efficiently.

Keywords Solanum . Whitefly resistance .

Trichome $\cdot$ Antibiosis $\cdot$ Antixenosis

\section{Introduction}

Bemisia tabaci (Gennadius) is one of the most important pests in agricultural crops worldwide. This 
whitefly is responsible for large reductions in crop yield and quality. Consequently, high costs are made for controlling it (Morales 2007). Bemisia tabaci causes direct damage by feeding on the phloem sap and it produces honeydew on which sooty molds can grow (Byrne and Miller 1990). This may result in physiological disorders of the plant, such as leaf wilting and irregular ripening of the fruit (Schuster et al. 1990; McCollum et al. 2004). However, the main problem caused by B. tabaci is the damage done by the viruses they transmit (Morales and Jones 2004).

Tomato cultivation and production, particularly in tropical countries is highly dependent on pesticides. However, pesticides are hazardous for the environment, growers and consumers. The exploitation of whitefly resistance originating from wild relatives of cultivated tomato is anticipated to be a more sustainable way of controlling whiteflies (Broekgaarden et al. 2011). Different levels of whitefly resistance have been reported for wild relatives of tomato including $S$. pennellii, S. habrochaites, S. habrochaites f. glabratum, S. pimpinellifolium, S. chilense (Maliepaard et al. 1995; Fancelli and Vendramim 2002; Muigai et al. 2002; Toscano et al. 2002; Muigai et al. 2003; Maruthi et al. 2003; Baldin et al. 2005).

Whiteflies prefer hairy leaves (Toscano et al. 2002), but the presence and density of type IV and VI trichomes has a negative effect on whitefly adult survival and oviposition rate (Channarayappa et al. 1992; Snyder et al. 1998). Exudates of these trichomes play a major role in whitefly resistance (Fancelli et al. 2005). Compounds implicated in whitefly resistance are acyl-sugars (Liedl et al. 1995; Mutschler et al. 1996), methyl-ketones and derivates of sesquiterpene carboxylic acid (Frelichowski and Juvik 2005), which might act as repellent and/or natural pesticides.

Mapping studies have identified Quantitative Trait Loci (QTLs) for reduced oviposition of Trialeurodes vaporariorum on chromosomes 1 and 12 in $S$. habrochaites f. glabratum (Maliepaard et al. 1995). Five QTLs for acyl sugars that confer whitefly resistance in S. pennellii LA176 were identified on chromosomes 2, 3, 4 and 11 (Mutschler et al. 1996). Solanum habrochaites LA1777 was also the source for QTLs showing a reduced egg deposition; these were located on the chromosomes 9, 10 and 12 (Momotaz et al. 2010). However, the combined effects of these QTLs explained only part of the variation present for whitefly resistance (Maliepaard et al. 1995; Lawson et al. 1997; Momotaz et al. 2010). From these results it was concluded that many genes might be involved in the whitefly resistance. When many genes/regions are involved, the introduction of the resistance trait from the wild relatives into commercial cultivars is often difficult. Therefore, the identification of genes with a major effect on resistance is of utmost importance. Preferably these resistance components should be present in close relatives of the cultivated tomato as introgression of the resistance is easier in these cases (Hogenboom 1972).

Two types of assessments are used to evaluate whitefly resistance: free-choice test and no-choice test (Romanow et al. 1991; Erb et al. 1994). In a freechoice test, whiteflies are given the choice between two or more different hosts of which it is able to choose the most preferred host(s). In a no-choice test, only one host is accessible for the whitefly and whiteflies that cannot feed on it will be hampered in their growth or die. Therefore, both antibiosis and antixenosis, which may result from repellence or attraction of whiteflies, is assessed in free-choice tests, whereas no-choice tests much more assess antibiosis (Baldin and Beneduzzi 2010). Reliable parameters for whitefly resistance assessments are very important. Parameters used to describe resistances are density and/or survival of a particular developmental stage of whitefly including adults, eggs or nymphs (Maliepaard et al. 1995; Fancelli and Vendramim 2002; Maruthi et al. 2003). Those parameters might measure similar or different resistance factors. Furthermore, relationships between resistance parameters and other supposedly related parameters like honeydew production, sooty-mold growth and plant damages have not been evaluated yet. Also, the development of whitefly resistance during the growth of the tomato plant has not been analyzed. Therefore, the objectives of the present study were to evaluate methods and resistance parameters used for whitefly resistance screening and to identify plant material that has high levels of resistance, preferably based on different mechanisms.

\section{Materials and methods}

Plant and whitefly material

Forty-six accessions of tomato and related wild species were obtained from the Centre for Genetic 
Resources (CGN) and the collection of Plant Research International (PRI)-The Netherlands, the Asian Vegetable Research and Development Center (AVRDC)_Taiwan and PT East West Seed Indonesia (EWSI)-Indonesia. In case clear differences were seen between individuals of one accession, they were considered as different accessions and they were given an individual number. This made the total number of evaluated accessions 52. Twenty-six accessions (Table 1) were screened in 2008 under free-choice condition in a screen house at EWSI, Purwakarta, West Java, Indonesia. Nine accessions (both resistant and susceptible) together with 26 until then unscreened accessions (Table 2) were evaluated under no-choice conditions using clip-on cages at Wageningen UR Plant Breeding, the Netherlands in 2009.

Non-viruliferous silverleaf whiteflies (B. tabaci B-biotype), from the collection of the Laboratory of Entomology, Wageningen University-the Netherlands or the Plant-Pathology Department of Bogor Agricultural University-Indonesia, were used for screening.

\section{Free-choice test}

Twenty-six tomato accessions were evaluated using a free-choice test in an insect proof screenhouse. The experiment was conducted from September until December 2008 at EWSI. The screenhouse protected the plants from out-side insects, heavy rainfall as well as strong sunlight. Seeds were sown in insect-free boxes and moved to clean cages after 1 week. One month later, three plants which had four or more shoots were selected from each accession. Four shoots of each selected plants were grafted onto 2 week old eggplants to avoid root diseases such as Fusarium wilt and nematodes. Two weeks after grafting, the plants were transplanted into a four liter-black bucket containing a rice husk and peat moss soil mixture. Four grafted plants originating from one original plant of each accession were placed in a square together on a table one meter above ground level. There were two lines on each table with $35 \mathrm{~cm}$ between lines, $20 \mathrm{~cm}$ between plants within the line and $100 \mathrm{~cm}$ between tables. The plants were supported by a bamboo stick. Branches and flowers were pruned in order to get one main stem. Two amaranth plants were placed in between every accessions (Fig. 1). There were three replications (derived from three individual plants) for each accession in the screenhouse. Five weeks after grafting, virus-free B. tabaci were introduced by placing heavily infested eggplants in the middle of the plants of each accession. During 1 week, the eggplants were shaken twice a day and left without watering. In this way, the whitefly adults were forced to look for other plants because the eggplants desiccated and died after 6 days (Muigai et al. 2003). The whitefly population development was studied by counting the number of adult whiteflies, eggs and nymphs, and also registering the whitefly related parameters including honeydew production, sooty-mold growth and plant damages at three different time points. The first evaluation was carried out on day 8 and 9 after infestation, the second evaluation was on day 22 and 23 and the third evaluation was on day 36 and 37 . The number of adult whiteflies was determined by counting directly on the abaxial leaf surface of lateral leaflets on the 3rd or 4th and 7th or 8th leaf from the apex; this direct counting is more reliable (less variance) than beating of the plant and counting in a tray (Gusmao et al. 2005). Egg and nymph numbers were determined on the same leaflets as where the adults were counted. The leaflets were cut from the plant to facilitate egg and nymph counting under a stereo microscope $(10 \times)$. Also the leaf area was measured. Honeydew production, sooty-mold growth and plant damages were visually scored on a scale of $0-4$. Scores used for honeydew production were $(0)$ no honeydew, (1) one to five honeydew droplets on one leaf, (2) honeydew present on two or more leaves, (3) severe honeydew (more than five honeydew droplets per leaflet) present on one or two leaves, (4) severe honeydew present on three or more leaves. Scores for sooty-mold growth were (0) no sooty mold, (1) some sooty mold present on one leaf, (2) sooty mold present on two or more leaves, (3) heavy sooty mold (thick and covering $>10 \%$ of leaflet area) present on one or two leaves and the others show no or a bit sooty mold, (4) heavy sooty mold present on three or more leaves. Scores for plant damages were (0) no necrosis or wilting, (1) light necrosis or wilting present of one leaf, (2) light necrosis or wilting present of two or more leaves, (3) heavy necrosis or wilting ( $>30 \%$ of leaf area) of two leaves but the plant is still growing, (4) heavy necrosis or wilting of three or more leaves and plant growth is inhibited or the plant is dead. 
Table 1 Means of adult whitefly density (whitefly $\mathrm{cm}^{-2}$ ) and egg density $\left(\mathrm{egg} \mathrm{cm}^{-2}\right.$ ) in the resistance screening of tomato accessions under free-choice condition

\begin{tabular}{|c|c|c|c|c|c|c|c|}
\hline \multirow[t]{3}{*}{ No. } & \multirow[t]{3}{*}{ Accession name } & \multicolumn{6}{|c|}{ Observation time $^{\mathrm{a}}$} \\
\hline & & \multicolumn{3}{|c|}{ Adult whitefly density } & \multicolumn{3}{|l|}{ Egg density } \\
\hline & & 1 & 2 & 3 & 1 & 2 & 3 \\
\hline 1 & $\begin{array}{l}\text { S. galapagense PRI95004/ } \\
\text { PY- } 8027\end{array}$ & 0.0 (a) [a] & 0.1 (a) [a] & 0.0 (a) [a] & 0.0 (a) [a] & 0.0 (a) [a] & 0.5 (a) [a] \\
\hline 2 & $\begin{array}{l}\text { S. galapagense PRI95004/ } \\
\text { PY-8030 }\end{array}$ & $0.5(\mathrm{e})[\mathrm{b}]$ & $0.5(\mathrm{cde})[\mathrm{b}]$ & $0.3(\mathrm{def})[\mathrm{a}]$ & $4.4(\mathrm{~d})[\mathrm{a}]$ & 8.1 (d) $[\mathrm{ab}]$ & $8.4(\mathrm{~cd})[\mathrm{b}]$ \\
\hline 3 & S. cheesmaniae CGN15916 & $2.1(\mathrm{jk})[\mathrm{a}]$ & $2.4(\mathrm{k})[\mathrm{a}]$ & $1.4(\mathrm{o})[\mathrm{a}]$ & $69.3(\mathrm{~m})[\mathrm{b}]$ & $52.1(\mathrm{k})[\mathrm{a}]$ & 65.2 (i) $[\mathrm{ab}]$ \\
\hline 4 & S. cheesmaniae CGN24039 & $0.8(\mathrm{~g})[\mathrm{a}]$ & 1.2 (ij) [a] & $0.9(\mathrm{mn})[\mathrm{a}]$ & 37.8 (j) [a] & 79.7 (l) [b] & 55.7 (i) $[\mathrm{ab}]$ \\
\hline 5 & S. cheesmaniae CGN17086 & $2.2(\mathrm{k})[\mathrm{b}]$ & $1.2(j)[a]$ & $0.9(\mathrm{mn})[\mathrm{a}]$ & $60.4(1 \mathrm{~m})[\mathrm{c}]$ & $14.5(\mathrm{fg})[\mathrm{b}]$ & 9.1 (d) [a] \\
\hline 6 & S. arcanum CGN14355 & $1.8(\mathrm{j})[\mathrm{b}]$ & 0.3 (b) $[\mathrm{a}]$ & $0.2(\mathrm{~cd})[\mathrm{a}]$ & $45.5(\mathrm{jk})[\mathrm{a}]$ & $62.1(\mathrm{k})[\mathrm{a}]$ & $37.7(\mathrm{gh})[\mathrm{a}]$ \\
\hline 7 & S. arcanum CGN15877 & $0.9(\mathrm{~g})[\mathrm{b}]$ & $0.6(\mathrm{ef})[\mathrm{b}]$ & 0.5 (ghi) [a] & 9.5 (ef) [a] & $12.8(\mathrm{ef})[\mathrm{ab}]$ & $13.1(\mathrm{e})[\mathrm{b}]$ \\
\hline 8 & S. glandulosum CGN15803 & 1.3 (hi) $[\mathrm{c}]$ & $0.9(\mathrm{gh})[\mathrm{b}]$ & 0.7 (jkl) [a] & 26.3 (i) [a] & 23.8 (i) [a] & $21.6(f)[a]$ \\
\hline 9 & S. glandulosum CGN14357 & $0.5(\mathrm{e})[\mathrm{a}]$ & $0.1(\mathrm{a})[\mathrm{b}]$ & $0.1(b)[b]$ & 10.2 (ef) [a] & 20.3 (hi) $[\mathrm{b}]$ & $22.1(f)[b]$ \\
\hline 10 & S. glandulosum CGN14358 & $1.0(\mathrm{~g})[\mathrm{b}]$ & 0.5 (cde) [a] & 0.5 (hij) [a] & $5.4(\mathrm{~d})[\mathrm{a}]$ & 10.9 (e) [a] & $9.0(\mathrm{~d})[\mathrm{a}]$ \\
\hline 11 & $\begin{array}{l}\text { S. habrochaites } \mathrm{f} . \\
\text { glabratum CGN24035 }\end{array}$ & $0.4(\mathrm{~cd})[\mathrm{a}]$ & 0.9 (ghi) [b] & $0.8(\operatorname{lm})[\mathrm{b}]$ & $5.1(\mathrm{~d})[\mathrm{a}]$ & 6.7 (d) $[a b]$ & $10.4(\mathrm{de})[\mathrm{b}]$ \\
\hline 12 & $\begin{array}{l}\text { S. habrochaites f. } \\
\text { glabratum PRI921237 }\end{array}$ & 0.2 (b) $[\mathrm{a}]$ & 0.2 (a) [a] & $0.2(\mathrm{c})[\mathrm{a}]$ & 1.3 (b) $[\mathrm{a}]$ & 2.9 (b) $[\mathrm{a}]$ & $30.4(\mathrm{~g})[\mathrm{b}]$ \\
\hline 13 & S. habrochaites CGN15391 & 1.4 (i) [a] & $3.5(1)[\mathrm{c}]$ & $2.3(\mathrm{p})[\mathrm{b}]$ & $18.8(\mathrm{~h})[\mathrm{a}]$ & $62.2(\mathrm{k})[\mathrm{b}]$ & $62.2(\mathrm{i})[\mathrm{b}]$ \\
\hline 14 & S. habrochaites LA1777 & $0.4(\mathrm{de})[\mathrm{a}]$ & 0.4 (bcd) [a] & 0.4 (fgh) [a] & $3.0(\mathrm{c})[\mathrm{a}]$ & $34.8(\mathrm{j})[\mathrm{b}]$ & $41.6(\mathrm{~h})[\mathrm{c}]$ \\
\hline 15 & S. habrochaites LA1033 & 0.1 (b) [a] & 0.8 (fg) [b] & $0.8(\mathrm{klm})[\mathrm{b}]$ & 2.3 (c) $[\mathrm{a}]$ & $58.5(\mathrm{k})[\mathrm{b}]$ & 54.0 (i) [b] \\
\hline 16 & $\begin{array}{l}\text { S. lycopersicoides } \\
\text { CGN23973 }\end{array}$ & $0.3(\mathrm{c})[\mathrm{a}]$ & $1.2(j)[b]$ & 1.1 (no) [b] & 28.1 (i) [a] & $35.8(j)[a]$ & $37.7(\mathrm{gh})[\mathrm{a}]$ \\
\hline 17 & $\begin{array}{l}\text { S. lycopersicum } \\
\text { PRI91117(control) }\end{array}$ & 1.5 (i) $[\mathrm{b}]$ & 0.9 (ghij) [a] & 0.7 (jkl) [a] & 11.3 (f) [a] & $39.6(j)[b]$ & $42.4(\mathrm{~h})[\mathrm{b}]$ \\
\hline 18 & $\begin{array}{l}\text { S. lycopersicum } \\
\text { EWSI } 24294\end{array}$ & $2.1(\mathrm{jk})[\mathrm{b}]$ & $0.6(\mathrm{ef})[\mathrm{a}]$ & 0.6 (ijk) [a] & $2.6(\mathrm{c})[\mathrm{a}]$ & $40.2(\mathrm{j})[\mathrm{b}]$ & $36.7(\mathrm{gh})[\mathrm{b}]$ \\
\hline 19 & $\begin{array}{l}\text { S. lycopersicum } \\
\text { EWSI } 49444\end{array}$ & $0.5(\mathrm{de})[\mathrm{a}]$ & $0.8(\mathrm{gh})[\mathrm{b}]$ & $0.8(\operatorname{lm})[\mathrm{b}]$ & $4.4(\mathrm{~d})[\mathrm{a}]$ & 4.7 (c) [a] & $6.6(\mathrm{bc})[\mathrm{a}]$ \\
\hline 20 & S. neorickii CGN15816 & $0.3(\mathrm{c})[\mathrm{a}]$ & $0.5(\mathrm{cde})[\mathrm{c}]$ & $0.4(\mathrm{efg})[\mathrm{b}]$ & $10.2(\mathrm{ef})[\mathrm{b}]$ & $4.6(\mathrm{c})[\mathrm{a}]$ & 5.4 (b) $[\mathrm{a}]$ \\
\hline 21 & S. neorickii CGN15815 & $0.7(f)[b]$ & $0.4(\mathrm{bc})[\mathrm{a}]$ & 0.3 (de) [a] & $14.6(\mathrm{~g})[\mathrm{b}]$ & 4.9 (c) $[a]$ & $6.2(\mathrm{bc})[\mathrm{a}]$ \\
\hline 22 & S. pennellii CGN23952 & $3.3(1)$ & & & & & \\
\hline 23 & S. peruvianum CGN17052 & $1.2(\mathrm{~h})[\mathrm{a}]$ & $0.6(\mathrm{de})[\mathrm{a}]$ & 0.5 (ghij) [a] & $4.3(\mathrm{~d})[\mathrm{a}]$ & $16.8(\mathrm{gh})[\mathrm{b}]$ & 19.1 (f) [b] \\
\hline 24 & S. peruvianum CGN17047 & $2.0(\mathrm{jk})[\mathrm{b}]$ & 0.9 (ghi) [a] & $0.8(\mathrm{klm})[\mathrm{a}]$ & $55.0(\mathrm{kl})[\mathrm{b}]$ & $33.0(j)[a]$ & $42.2(\mathrm{~h})[\mathrm{ab}]$ \\
\hline 25 & $\begin{array}{l}\text { S. pimpinellifolium } \\
\text { CGN14401 }\end{array}$ & $0.5(\mathrm{e})[\mathrm{a}]$ & $1.2(j)[b]$ & $1.2(\mathrm{o})[\mathrm{b}]$ & 8.1 (e) [a] & $37.8(j)[b]$ & $35.8(\mathrm{gh})[\mathrm{b}]$ \\
\hline 26 & $\begin{array}{l}\text { S. pimpinellifolium } \\
\text { PRI91059 }\end{array}$ & 0.7 (f) [a] & 1.1 (hij) [b] & $0.8(\operatorname{lm})[\mathrm{ab}]$ & 10.9 (f) [a] & 12.4 (ef) [a] & $13.6(\mathrm{e})[\mathrm{a}]$ \\
\hline
\end{tabular}

The mean followed by different letters in the parenthesis within columns are different according to Duncan's multiple range test and different letters in the brackets within lines are different according to Fisher's student test in $0.05 p$-significance

a Observation time: (1) 8 and 9 days after infestation; (2) 22 and 23 days after infestation; and (3) 36 and 37 days after infestation

Data on adults, eggs, nymphs and leaf area in the free-choice test were used to determine adultwhitefly density (number of adult whiteflies $/ \mathrm{cm}^{2}$ of leaf), egg density (number of eggs $/ \mathrm{cm}^{2}$ ), and nymphal density (number of nymphs $/ \mathrm{cm}^{2}$ ). Log transformation was used to normalize adult-whitefly density data and $\ln$ transformation for egg and nymphal density. 
Table 2 Means of whitefly resistance parameters and type-trichome density in clip-on cage test

\begin{tabular}{|c|c|c|c|c|c|c|c|}
\hline \multirow[t]{2}{*}{ No. } & \multirow[t]{2}{*}{ Accession name } & \multicolumn{4}{|c|}{ Whitefly resistance parameters } & \multicolumn{2}{|c|}{$\begin{array}{l}\text { Trichome density (trichomes/ } \\
\mathrm{mm}^{2} \text { ) }\end{array}$} \\
\hline & & $\begin{array}{l}\text { Adult } \\
\text { survival }\end{array}$ & $\begin{array}{l}\text { Oviposition } \\
\text { rate }\end{array}$ & $\begin{array}{l}\text { Pre-adult } \\
\text { survival }\end{array}$ & $\begin{array}{l}\text { Development } \\
\text { period }\end{array}$ & $\begin{array}{l}\text { Type } \\
\text { IV }\end{array}$ & $\begin{array}{l}\text { Type } \\
\text { V }\end{array}$ \\
\hline 1 & S. galapagense PRI95004/PY-8027 & $0.0 \mathrm{a}$ & $0.1 \mathrm{a}$ & $0.0 \mathrm{a}$ & No data & 30 & 0 \\
\hline 2 & S. galapagense PRI95004/PY-8028 & $0.98 \mathrm{efg}$ & 6.9 hij & $0.9 \mathrm{hi}$ & $22.7 \mathrm{abc}$ & $0^{(a)}$ & 40 \\
\hline 3 & S. galapagense PRI95004/PY-8029 & 0.97 efg & $9.7 \mathrm{klm}$ & 0.9 ghi & 23.5 hijk & $0^{(\mathrm{a})}$ & 19 \\
\hline 4 & S. galapagense PRI95004/PY-8030 & 0.96 ef & $5.7 \mathrm{gh}$ & 0.8 fghi & $23.1 \mathrm{def}$ & $0^{(\mathrm{b})}$ & 20 \\
\hline 5 & S. galapagense PRI95004/PY-8031 & 0.97 ef & $5.6 \mathrm{gh}$ & 0.8 fghi & $23.7 \mathrm{jkl}$ & $0^{(\mathrm{a})}$ & 27 \\
\hline 6 & S. cheesmaniae LA1448 & $1.0 \mathrm{~g}$ & $10.7 \mathrm{~lm}$ & 0.9 hi & $23.6 \mathrm{ijkl}$ & 0 & 17 \\
\hline 7 & S. arcanum CGN15531 & 0.98 efg & $9.5 \mathrm{klm}$ & 0.9 ghi & $23.6 \mathrm{ijkl}$ & 0 & 35 \\
\hline 8 & S. arcanum CGN14356 & $0.99 \mathrm{fg}$ & $9.4 \mathrm{klm}$ & 0.9 ghi & $22.8 \mathrm{bcd}$ & 0 & 34 \\
\hline 9 & S. arcanum CGN15801 & 0.97 efg & 3.8 ef & $0.8 \mathrm{ghi}$ & $23.7 \mathrm{jkl}$ & 0 & 2 \\
\hline 10 & S. arcanum CGN15392 & $0.99 \mathrm{fg}$ & $5.2 \mathrm{fgh}$ & $0.3 \mathrm{~b}$ & $24.5 \mathrm{~m}$ & 0 & 45 \\
\hline 11 & S. arcanum CGN15799 & 0.97 efg & $4.0 \mathrm{fg}$ & 0.9 ghi & 23.91 & 0 & 25 \\
\hline 12 & S. glandulosum CGN14357 & $0.99 \mathrm{fg}$ & $10.1 \mathrm{klm}$ & 0.9 ghi & 24.01 & 0 & 56 \\
\hline 13 & S. habrochaites f. glabratum CGN15792 & $0.79 \mathrm{bc}$ & $0.8 \mathrm{abc}$ & $0.5 \mathrm{cde}$ & 23.2 efgh & 7 & 7 \\
\hline 14 & S. habrochaites f. glabratum CGN15879 & $0.72 \mathrm{~b}$ & $1.8 \mathrm{~cd}$ & 0.7 cde & 23.3 efghi & 3 & 13 \\
\hline 15 & S. habrochaites f. glabratum PI134417 & $0.72 \mathrm{~b}$ & $0.3 \mathrm{ab}$ & $0.4 \mathrm{~cd}$ & $25.9 \mathrm{n}$ & 29 & 0 \\
\hline 16 & S. habrochaites f. glabratum PI134418 & $0.0 \mathrm{a}$ & $0.2 \mathrm{a}$ & $0.0 \mathrm{a}$ & No data & 36 & 0 \\
\hline 17 & S. habrochaites f. glabratum PRI921237 & $0.82 \mathrm{c}$ & $1.9 \mathrm{~cd}$ & $0.6 \mathrm{~cd}$ & 23.3 fghij & 21 & 10 \\
\hline 18 & S. habrochaites LA1718 & $0.78 \mathrm{bc}$ & $0.3 \mathrm{ab}$ & $0.0 \mathrm{a}$ & No data & 5 & 11 \\
\hline 19 & S. habrochaites LA4137 & 0.98 efg & 4.3 ef & 0.6 cdef & $22.6 \mathrm{abc}$ & 8 & 0 \\
\hline 20 & S. habrochaites LA1777 & $0.89 \mathrm{~d}$ & $1.2 \mathrm{bc}$ & $0.4 \mathrm{bc}$ & $22.6 \mathrm{ab}$ & 14 & 0 \\
\hline 21 & S. lycopersicum Moneymaker & $1.0 \mathrm{~g}$ & $6.3 \mathrm{hij}$ & 0.9 fghi & $23.8 \mathrm{kl}$ & 0 & 30 \\
\hline 22 & S. lycopersicum PRI91117 & $1.0 \mathrm{~g}$ & 5.9 ghi & 0.6 cde & $23.6 \mathrm{ijkl}$ & 0 & 24 \\
\hline 23 & S. neorickii CGN15816 & 0.97 efg & $5.1 \mathrm{fgh}$ & 0.9 hi & $23.1 \mathrm{def}$ & 0 & 43 \\
\hline 24 & S. neorickii LA2072 & $0.98 \mathrm{efg}$ & $5.2 \mathrm{fgh}$ & 0.7 defg & $22.5 \mathrm{a}$ & 0 & 31 \\
\hline 25 & S. neorickii LA2133 & $0.83 \mathrm{c}$ & $2.4 \mathrm{de}$ & 0.7 cdef & 23.0 cde & 25 & 0 \\
\hline 26 & S. peruvianum CGN17052 & $0.94 \mathrm{e}$ & 3.6 ef & 0.9 ghi & $23.6 \mathrm{ijkl}$ & 0 & 16 \\
\hline 27 & S. peruvianum CGN17046 & $1.0 \mathrm{~g}$ & $10.7 \mathrm{~lm}$ & $1.0 \mathrm{i}$ & 23.4 fghij & 0 & 17 \\
\hline 28 & S. peruvianum PI126928/PY-8037 & $0.99 \mathrm{fg}$ & $8.1 \mathrm{jk}$ & 0.9 ghi & $23.1 \mathrm{defg}$ & 0 & 44 \\
\hline 29 & S. peruvianum PI126928/PY-8038 & $0.99 \mathrm{fg}$ & $11.4 \mathrm{~m}$ & 0.9 hi & 23.5 ghijk & 0 & 51 \\
\hline 30 & S. pimpinellifolium PRI91059 & 0.98 efg & $10.9 \mathrm{~lm}$ & 0.9 hi & 22.9 bcde & 0 & 28 \\
\hline 31 & S. pimpinellifolium LA1261 & 0.98 efg & $8.6 \mathrm{jkl}$ & 0.9 ghi & $22.8 \mathrm{abcd}$ & 0 & 32 \\
\hline 32 & S. pimpinellifolium LA1584/PY-8040 & $0.71 \mathrm{~b}$ & $0.6 \mathrm{ab}$ & 0.7 efgh & $23.3 \mathrm{efgh}$ & 21 & 2 \\
\hline 33 & S. pimpinellifolium LA1584/PY-8039 & 0.97 efg & 6.7 hij & $0.9 \mathrm{ghi}$ & $22.8 \mathrm{bcd}$ & $0^{(\mathrm{b})}$ & 26 \\
\hline 34 & S. pimpinellifolium CGN15912 & 0.97 efg & 7.6 hij & $0.6 \mathrm{~cd}$ & $22.8 \mathrm{bcd}$ & 0 & 21 \\
\hline 35 & S. pimpinellifolium CGN15808 & $0.99 \mathrm{fg}$ & $7.8 \mathrm{ijk}$ & 0.9 hi & 23.6 hijk & 0 & 20 \\
\hline
\end{tabular}

Mean followed by different letters within columns are different by Duncan's multiple range test in $0.05 p$-significance

(a) Type IV trichomes were not found on the leaf lamina, but a few were present on the stem and leaf petioles

(b) A few type IV trichomes were found on the leaf lamina 


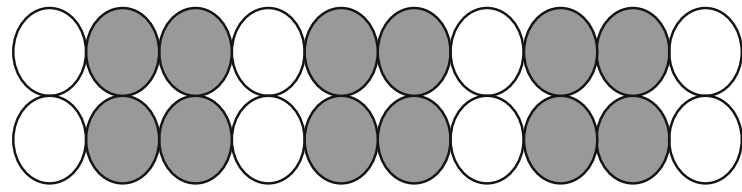

Fig. 1 Setup in the screenhouse, four grafts of one individual plant of an accession are grown together ( grey) and are separated from four plants of the next accession by two amaranth plants (white). Whitefly infested leaves were put in between the four grafts

\section{No-choice tests}

No-choice tests were carried out in April and May 2009 by using clip-on cages (Maliepaard et al. 1995) and leaf discs in Wageningen, The Netherlands. Seeds of each tomato accession were sown in peat-moss soil in a sowing box and after the third leaf stage, the plants were transplanted into $1.5 \mathrm{~L}$ pots containing peat-moss soil and placed on stainless steel tables in two randomized blocks (compartments) with one plant per accession per block. The temperature in the compartments was set to $20 / 15{ }^{\circ} \mathrm{C}$ (day/night), a 16L:8D photoperiod was used and relative humidity was kept at $70 \%$. One week before infestation, the temperature was raised gradually until it reached 27/18 ${ }^{\circ} \mathrm{C}$ (day/night) two days before infestation. Two plants per accession were ready to be tested with clipon cages and leaf discs.

\section{Clip-on cage test}

Plants were infested with whiteflies 6 weeks after sowing. Five synchronized whitefly females (one to two days old) ( $n$ ) were anesthetized with $\mathrm{CO}_{2}$ and put into a clip-on cage $(2 \mathrm{~cm}$ in diameter and $1 \mathrm{~cm}$ in height) and placed immediately on the abaxial surface of a leaflet of the 3rd or 4th leaf from the apex. Five clip-on cages were attached per plant. Four days after infestation $(d)$ the clip-on cages were removed from the leaves and the death and living whiteflies $(m)$ were counted. The number of eggs $(e)$ was counted under a stereo microscope $(10 \times$ magnification). The clip-on cages were reassembled at their original positions on each leaflet before new adult whiteflies started to emerge from the eggs. The emerging adults $\left(a_{i}\right)$ were counted and removed from the cages every day $\left(t_{i}\right)$ during a week. Pupal cases $(p)$ were counted 7 days after the first-emerging adult whiteflies. Adult survival
(AS), oviposition rate (OR), pre-adult survival (PS) and development periods (DP) were calculated by using the equations (Maliepaard et al. 1995) as shown below.

$$
\begin{aligned}
A S & =\left(\frac{m}{n}\right)^{1 / d} /(\text { day }) \\
O R & =\frac{2 e}{d(m+n)}(\text { eggs/female/day }) \\
P S & =p / e(\text { whiteflies/egg }) \\
D P & =\frac{\left(\sum t_{i} \cdot a_{i}\right)}{\sum a_{i}} \text { (days) }
\end{aligned}
$$

An Arcsin transformation was used to normalize data of adult survival and pre-adult survival, and a square-root transformation for oviposition rate and development period.

\section{Leaf disc test}

Nine accessions, selected on the basis of adult survival and oviposition rate in the clip-one cage test were used for the leaf disc test. One week after whitefly infestation in the clip-on cages test, four young leaflets at the 3rd, 4th or 5th node from the top were cut from each accession and put on a petri dish containing $1 \%$ agar and covered with paper which had four symmetrical holes (Fig. 2). Each hole was two $\mathrm{cm}$ in diameter and therefore of the same size as the area under the clip-on cage. Twenty synchronized whitefly females (1-2 days old) were anesthetized with $\mathrm{CO}_{2}$ and placed on the paper, the disc was closed with a cage (eight $\mathrm{cm}$ in diameter and six $\mathrm{cm}$ in height) containing nylon mesh (for air circulation). The cages were reversed and placed in the climate room at $27{ }^{\circ} \mathrm{C}$, a relative humidity of $70 \%$ and a photoperiod of $16 \mathrm{~L}: 8 \mathrm{D}$. Alive and dead whiteflies as well as egg number were counted 4 days after infestation. The test was done in three replications. Adult survival and oviposition rate were calculated and normalized in the same way as in the clip-on cage test.

\section{Observation of trichomes}

Classification and identification of trichome types were made according to Luckwill (1943) based on the morphology and presence of glands. The leaflet opposite of the leaflet with the clip-on cage was taken 
from the plant. The trichomes were identified and counted in an area of $11.11 \mathrm{~mm}^{2}(1 / 3 \times 1 / 3 \mathrm{~cm})$ on the right and left side of main vein at the leaflet base using a stereo dissecting microscope (40-100 times magnification).

\section{Statistical analysis}

Pearson's $r$ correlation coefficients were calculated between whitefly parameters in both no-choice and free-choice tests and between whitefly resistance parameters and trichome density in no-choice test. Spearman's rho correlation was used to calculate the correlation between honeydew production, sootymold growth and plant damages in free-choice test. Data were also subjected to two-way repeated measurement analysis of variance for free-choice test and analysis of variances for no-choice tests. Afterward, mean differentiation by Duncan's Multiple Range Test (DMRT) for accession and Least Significant Difference (LSD) for observation time of each accession. Statistical analysis was conducted with the software package SPSS 17.0 for Windows (SPSS Inc., Chicago, IL).

\section{Results}

Whitefly resistance in free-choice test

In the free-choice test, several parameters were measured including adult-whitefly, egg and nymphal density at three successive time points as well as honeydew production, sooty-mold growth and plant damage. Table 3 shows the Pearson's $r$ correlations between the different parameters. The data underlying these can be found in the Supplementary Tables 1,2,3, 4. Significant correlations were named slight if $\mathrm{r}=0.20-0.40$ moderate from 0.41 to 0.60 , high from 0.61 to 0.80 and very high from $0.81-1.00$. Adultwhitefly density was moderately correlated with egg and nymphal density, whereas, egg and nymphal density had a high correlation. Honeydew production was strong correlated with nymphal density, but less to adult-whitefly and egg density (Table 3). Table 1 shows for all accessions the development of adult and egg density over time in the free-choice test. The results of nymphal density, honeydew production, sooty-mold growth and plant damages are presented in the Supplementary Tables 1, 2, 3, 4. Adult-whitefly and egg density on most tomato accessions changed over time. For instance, the number of adults decreased sharply over time for $S$. arcanum CGN14355 and $S$. lycopersicum EWSI24294, whereas, the number of adults increased on most $S$. habrochaites and $S$. pimpinellifolium accessions. Furthermore, egg density also decreased on S. cheesmaniae CGN17086, S. neorickii CGN15816 and S. neorickii CGN15815, whereas egg density for all $S$. habrochaites accessions developed the other way around. The changes mostly occurred between the first and second observation time and less between the second and third. The change can also be seen from the correlation between the three time points. The correlation of adult-whitefly density between first and second observation time was 0.454 $(N=75)$, between first and third observation time $0.413(N=75)$ and the correlation between second and third observation time was $0.931(N=75)$. The correlations between observations for the other parameters are presented in Supplementary Table 5.
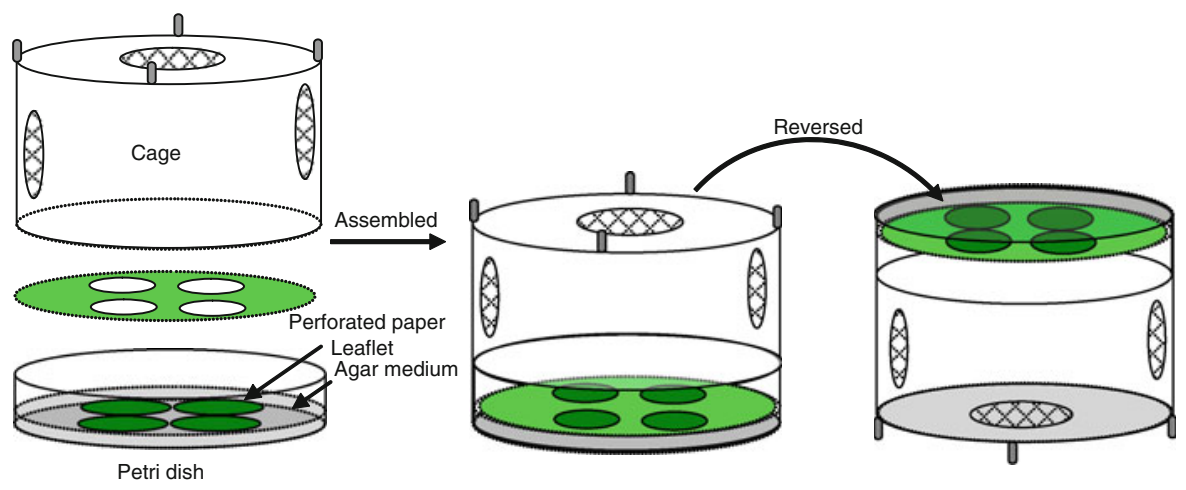

Fig. 2 Experimental setup for the leaf disc test 
Table 3 Pearson's r correlation between parameters used in the whitefly resistance screening of tomato accessions in the free-choice experiment

\begin{tabular}{|c|c|c|c|c|c|c|}
\hline Parameters & WD & ED & ND & HD & SM & DM \\
\hline Whitefly density (WD) & & $0.48 * *(228)$ & $0.43 * *(225)$ & $0.38 * *(225)$ & $0.35 * *(228)$ & $0.24 * *(228)$ \\
\hline Egg density (ED) & & & $0.86 *(225)$ & $0.49 * *(225)$ & $0.20 * *(228)$ & $0.35 * *(228)$ \\
\hline Nymphal density (ND) & & & & $0.62^{* *}(225)$ & $0.26 * *(225)$ & $0.47 * *(225)$ \\
\hline Honeydew (HD) & & & & & $0.30 * *(234)$ & $0.50 * *(234)$ \\
\hline Sooty mold (SM) & & & & & & $0.61^{* *}(234)$ \\
\hline Plant damages (DM) & & & & & & \\
\hline
\end{tabular}

\footnotetext{
** Correlation is significant at the 0.01 level (two-tailed)

* Correlation is significant at the 0.05 level (two-tailed)
}

Solanum galapagense PRI95004/PY-8027 showed the lowest adult density at all time points. S. habrochaites f. glabratum PRI921237 behaved similarly, whereas other accessions such as $S$. habrochaites LA1033 showed only a low adult density at the first observation point but not at the other two. For $S$. glandulosum CGN14357 this was the opposite.

The lowest egg density at all time-points was also found on S. galapagense (PRI95004/PY-8027). Some accessions were less preferred at a particular developmental stage. For instance, on all $S$. habrochaites $\mathrm{f}$. glabratum accessions there were fewer eggs at the first and second observation point compared to the third. On S. habrochaites LA1777, LA1033 and S. lycopersicum EWSI24294 the number of eggs was low at the first observation point, compared to observations 2 and 3. For $S$. lycopersicum EWSI49444, S. neorickii CGN15816 and CGN15815 it was the opposite; they had fewer eggs during the second and third observation.

Whitefly resistance in no-choice tests

Two types of no-choice tests were used; clip-on cage and leaf disc tests. The results of the clip-on cage test are shown in Table 2. Pearson's correlation coefficient between adult survival (AS) and oviposition rate (OR) was $0.726(N=315)$, between AS and pre-adult survival (PS) was $0.591(N=315)$ and between OR and PS was $0.623(N=288)$. The development period (DP) did not correlate with AS, OR or PS $(-0.12$ to $0.07 ; N=288$ ). Adult survival, OR, PS and DP were not significantly different between the two blocks used and among replications. However, PS was different between the two blocks ( $p$ value $<0.05$ ). There were significant differences among tomato accessions for all parameters ( $p$ values $<0.01$ ) for instance the adult survival ranged from 0.0 to 1.0 (Table 2). Solanum pimpinellifolium LA1584/PY-8040 and four S. habrochaites accessions were slightly less resistant than the two most resistant accessions ( $S$. galapagense PRI95004/PY-8027 and S. habrochaites f. glabratum PI134418). Oviposition rate ranged from 0.1 to 11.4 eggs female ${ }^{-1}$ day $^{-1}$. Six accessions ( $S$. galapagense PRI95004/PY-8027, S. habrochaites f. glabratum PI134418, PI134417, CGN15792, S. habrochaites LA1718 and S. pimpinellifolium LA1584/PY-8040), with a low AS, were also having the lowest OR (Table 2). Three accessions ( $S$. galapagense PRI195004/PY-8027, S. habrochaites f. glabratum PI134418 and S. habrochaites LA1718) which were low in AS and OR, were also low in PS. The development period ranged from 22.5 to 25.9 days. The shortest DP was found on S. neorickii LA2072, S. pimpinellifolium LA1261, S. galapagense PRI95004/ PY-8028, S. habrochaites LA4137 and LA1777.

In the leaf disc test we compared 9 accessions to the clip-on cage test. The resistance levels observed for the resistant ( $S$. galapagense PRI95004/PY-8027, $S$. habrochaites f. glabratum PI134417 and PI134418, and S. pimpinellifolium LA1584/PY-8040), moderately resistant ( $S$. habrochaites f. glabratum CGN15879 and S. habrochaites LA1718) and susceptible accessions (S. galapagense PRI95004/PY-8028, S. peruvianum PI126928/PY-8038 and S. lycopersicum MM) were similar in the leaf disc and clip-on cage tests (additional Table 6). This was also clear from the high correlation between the leaf disc and clip-on cage tests $(\mathrm{R}=0.88$ for AS and $\mathrm{R}=0.93$ for $\mathrm{OR})$. 
Table 4 Pearson correlation between parameters in free-choice and no-choice tests $(N=9)$
** Correlation is significant at the 0.01 level (two-tailed)

* Correlation is significant at the 0.05 level (two-tailed)

\begin{tabular}{llllll}
\hline Parameters & Observation time & \multicolumn{2}{l}{ Clip-on cage test } \\
\cline { 3 - 6 } & & AS & OR & PS & DP \\
\hline Adult whitefly & 1 & $0.79^{*}$ & 0.55 & 0.54 & 0.66 \\
& 2 & 0.59 & 0.45 & 0.47 & 0.44 \\
Egg density & 3 & $0.70^{*}$ & 0.46 & 0.52 & 0.63 \\
& 1 & $0.87^{* *}$ & $0.87 * *$ & $0.79 *$ & 0.66 \\
Nymphal density & 2 & $0.74^{*}$ & 0.42 & 0.33 & 0.65 \\
& 3 & 0.64 & 0.22 & 0.18 & $0.74 *$ \\
& 1 & $0.76^{*}$ & $0.81 * *$ & $0.80^{* *}$ & 0.59 \\
& 2 & $0.81^{*}$ & 0.54 & 0.48 & $0.68 *$ \\
& 3 & $0.86^{* *}$ & 0.48 & 0.46 & $0.84 * *$ \\
\hline
\end{tabular}

Correlation between no-choice and free-choice tests

Nine accessions were tested in both free-choice and clip-on cage tests. Pearson correlation between parameters in free-choice and no-choice tests can be seen in Table 4. Adult survival correlated with adultwhitefly, egg and nymphal density at all time-points. On the other hand, OR and PS highly correlated with egg and nymphal density at the first observation time only.

Trichome diversity and its relationship to whitefly resistance parameters

Of the seven types of trichomes (I-VII) type IV and/or $\mathrm{V}$ trichomes were predominantly present on the abaxial leaf surface. Type I, III and VII were mostly absent. Type VI was present on the abaxial side of the leaves of all accessions, but in low numbers. It was frequently found on stem and leaf petioles. Trichome type I and/or III were found on the stem of the plant, leaf petiole and on the veins and only rarely on the adaxial leaf surface. The number of type IV and V trichomes was different among the tomato accessions (Table 2). The occurrence of type IV trichomes ranged from 0.0 to 36.2 trichomes $/ \mathrm{cm}^{2}$. All accessions which were resistant as shown by low AS, OR and PS had type IV trichomes causing a high correlation between type IV trichomes and whitefly resistance parameters (Table 5). Most susceptible accessions had many type $\mathrm{V}$ trichomes and no type IV trichomes, which also shows from the correlation between susceptibility and resistance with presence of trichomes $\mathrm{V}$ and IV respectively (Table 5). However, three accessions, $S$.
Table 5 Pearson's $\mathrm{r}$ correlation between parameters in nonchoice test with different types of trichomes $(N=140$ for adult survival, oviposition rate and pre-adult survival; and $N=128$ for developmental period)

\begin{tabular}{lccc}
\hline Parameters & \multicolumn{3}{l}{ Trichome density } \\
\cline { 2 - 4 } & Type IV & Type V & Type VI \\
\hline Adult survival & $-0.82 * *$ & $0.67 * *$ & $-0.42 * *$ \\
Oviposition rate & $-0.79 * *$ & $0.75 * *$ & $-0.30 * *$ \\
Pre-adult survival & $-0.64 * *$ & $0.60 * *$ & $-0.24 * *$ \\
Developmental periods & 0.07 & 0.03 & 0.06
\end{tabular}

**Correlation is significant at the 0.01 level (two-tailed)

*Correlation is significant at the 0.05 level (two-tailed)

arcanum CGN 14355 and S. glandulosum CGN14358, which were evaluated in free-choice test, and $S$. arcanum CGN15392 which was only evaluated in the clip-on cage test, did combine the absence of type IV trichomes with whitefly resistance.

\section{Discussion}

Parameters for whitefly resistance assessments

\section{Whitefly developmental stages as parameter} for resistance

In the initial stage of a whitefly infestation the adults have to choose a host plant for feeding and/or oviposition. Selection of the host plant may depend on several factors such as leaf architecture and color (Sippell et al. 1987), leaf pubescence and trichome type and density (McAuslane 1996; Snyder et al. 1998; 
Toscano et al. 2002), cuticle thickness (Channarayappa et al. 1992) and compounds that play a role in repelling or attracting whiteflies (Chermenskaya et al. 2009). Subsequent stages of the whitefly development depend on the initial selection or survival of the adults. Therefore the different stages in the whitefly development may be correlated in a free-choice test and this is also what we observe (Table 3). However, some of these resistance parameters are much stronger correlated than others. Although very significant, we see a correlation of only 0.48 between whitefly density and egg density on a host plants whereas egg density and nymph density are highly correlated (0.86). Lower correlation between adult density and egg or nymphal densities shows that resistance factors in adult density and egg/nymphal density may be different.

The high correlation between egg and nymphal densities suggest that egg hatching is not influenced. All nymphal stages including instar 1 to instar 4 were observed, so oviposition (egg density) was apparently affected by an antibiosis and/or preference factor(s) which were recognized by the adult female. This hypothesis was already proposed by van Lenteren and Noldus (1990) and Nomikou et al. (2003) who suggest that oviposition preference and host plant selection by the female whitefly has a profound effect on the fitness of its offspring.

Adult and egg density in free-choice test, especially at the beginning of the infestation, may be influenced by preference factors. However, the high correlation between whitefly density in the free-choice test and adult survival in no-choice test (Table 4), which much more assesses antibiosis than antixenosis, points at antibiotic factors as the main cause for the differences. Only the first observation showed a high correlation of egg and nymphal densities in the free-choice test and oviposition rate and pre-adult survival in the no-choice test (Table 4). However, the correlation is only there for egg and nymphal density. This observation time was relatively similar with that for oviposition rate and pre-adult survival in clip-on cage test; plants were about 6 weeks old. The poorer correlations for the other time points may therefore be caused by the different development changes of the host plant, which may affect resistance. The level of resistance of some accessions increased whereas for others the level decreased (Table 1).

Adult survival in the no-choice test highly correlated with other parameters determined in the same test and also with all parameters in the choice test (Table 4). This strongly suggests that factor(s) affecting adult survival are the major factor in tomato defense. Antibiotic agents, such as acyl-sugar and methyl ketones, have been identified affecting insect growth in some tomato wild relatives (Lin et al. 1987; Liedl et al. 1995).

The development period was not correlated to the other parameters. This indicates that it is regulated by other mechanisms and in our studies it is not playing a major role in whitefly resistance. Also others showed the developmental period was not simply linked to adult survival, oviposition rate and pre-adult survival (Romanow et al. 1991; Bas et al. 1992; van Giessen et al. 1995).

\section{Correlation between honeydew production, sooty mold growth, plant damage and whitefly resistance}

Whiteflies produce honeydew (Blua and Toscano 1994) which contains several sugars and amino acids (Byrne and Miller 1990), that are good substrates for sooty-mold growth (McCollum et al. 2004). Whitefly infestation and sooty-mold growth were found to result in physiological disorder and plant damages (Morales 2007). Our results show that only nymphal density correlates with honeydew production (Table 3), although both adult whiteflies and nymphs produce honeydew (Blua and Toscano 1994). The high correlation is most likely due to the fact that honeydew production of nymphs is much more regular than that of adults. Plant damage did slightly to moderately correlate with resistance parameters as well as honeydew production, and it highly correlated with sooty-mold growth (Table 3 ). Sooty mold growth contributes in several ways to the plant damage as it inhibits light transmission into leaf tissue which result in reducing photosynthesis and physiological disorders (Filho and Paiva 2006; Morales 2007).

\section{Leaf disc test for whitefly resistance assessment}

Adult survival and oviposition rate in the leaf disc test is highly correlated with adult survival and oviposition rate in the clip-on cage test. Therefore, leaf disc test may be a good alternative for whitefly resistance assessment using the clip-on cages. As an in vitro test, the leaf disc test has some advantages. It allows conducting the test in a more controlled environment, 
less space is needed and it is safer especially when there are viruses involved in the experiment. It is also possible to carry out the test in a free-choice situation. However, some improvements such as the addition of appropriate nutrition and antifungal agents are needed when one would like to assess the whole whitefly life cycle. The fact that we find a high correlation between the clip-on cage (in vivo test) and the leaf disc test (in vitro test) suggests that detaching or wounding tomato leaves does not or slightly effect on the resistance. Similar results were reported for an in vitro test used to screen for thrips resistance in pepper (Maharijaya et al. 2011).

Whitefly resistance and preference in accessions of tomato wild relatives

\section{Level of whitefly resistance and preference in tomato accessions}

The results show accession dependent responses to the whiteflies in the no-choice and choice test. Some accessions were fully resistant, whereas others were completely susceptible (Tables 2, 3). One of the most striking examples was accession PRI95004. This $S$. galapagense (syn: Lycopersicum cheesmanii f. minor) accession is derived from the a genetically heterogeneous $S$. galapagenense accession. Both morphological characters and trichome types varied between individuals of this accession. In total five different homogenous groups were found, of which PY-8027 and PY-8030 are shown (Tables 1, 2). Solanum galapagense PY-8027, was highly resistant with high density of type IV trichomes. The four others were susceptible and were lacking the high density of type IV trichomes, like PY-8030. The resistant selection PY-8027 gave no adult survival and almost no oviposition in the no-choice test and was not preferred in the free-choice tests. The accession has never before been reported to be resistant to B. tabaci. Solanum galapagense is genetically close to commercial tomato (Perralta et al. 2008) which may make it easier to use in commercial breeding programs. After testing with Keiferia lycopersicella (Walsingham) less damage and lower numbers of larvae were found on another S. galapagense accession (Schuster 1977).

The level of whitefly resistance in the S. habrochaites accessions was variable. This species has been exploited as resistance source to several pests (Lin et al. 1987; Eigenbrode and Trumble 1993; Momotaz et al. 2010). In our no-choice test $S$. habrochaites LA 1718 showed some level of resistance (Table 2), due to a low oviposition rate. In the choice assay (Table 1) LA1777 and LA1033 showed resistance only in the beginning of whitefly infestation and they became more susceptible over time. Previous research showed that LA 1777 was less preferred in a choice test (Muigai et al. 2003) and less virus incidence was detected after infestation by viruliferous whitefly (Maruthi et al. 2003). In our evaluation most accessions of $S$. habrochaites f. glabratum were not preferred by whitefly with PI134418 being the most resistant accession. Our results confirm earlier results (Toscano et al. 2002; Fancelli and Vendramim 2002; Muigai et al. 2003; Baldin et al. 2005).

Solanum pimpinellifolium LA1584 also showed heterogeneity within the accession. Resistance observed was due to a low adult survival and oviposition rate. This accession was also reported as resistant due to low nymphal survival (Fancelli and Vendramim 2002), but it was preferred in a freechoice test (Baldin et al. 2005). Some other accessions from $S$. arcanum, $S$. glandulosum, S. lycopersicum and S. neorickii showed partial resistance for adult density, egg density or pre-adult survival. From those accessions, only $S$. arcanum was reported to be partially resistant to whitefly (Channarayappa et al. 1992; Muigai et al. 2003).

\section{Whitefly resistance changes over time}

The number of whiteflies that can be sustained by an accession depends on the suitability of the host as food resources (Hirano et al. 1995), resistance levels (antibiosis) and microclimatic factors (Horowitz 1986). Resistance of most accessions changed between the first and second observation (Table 1). On the other hand, only minor changes occurred between the second and the third observation time for most accessions. These results show that successful whitefly colonization on a new host is largely dependent on host suitability at the time the first infestation takes place. During that period, interactions between the host plant and phloem-feeding insects occur that may change host plant suitability (Broekgaarden et al. 2010). The interaction can increase the resistance in the host plant (induction) or decrease it (suppression) (Broekgaarden et al. 2007). Bas et al. (1992) also 
observed resistance differences between younger and older plants. Effects of tomato age and infestation time were also reported in the resistance of tomato plants against potato moth (Phthorimala operculella) (Gurr and McGrath 2001).

Influence of trichome types on whitefly preference and resistance

Trichomes have been considered as the most important pest resistance factor. Seven types of trichomes are known in tomato of which type I, IV, VI and VII are glandular trichomes, and type II, III and V are nonglandular trichomes (Gurr and McGrath 2001; Simmons and Gurr 2005).

The presence, density and distribution of the trichome types depends on the tomato genotype, organs/tissue, age and environmental conditions (Wilkens et al. 1996; Gurr and McGrath 2001; Kang et al. 2010). Solanum galapagense has no type II and III, few type I, VI and VII, very few type V, but very abundant type IV trichomes (Simmons and Gurr 2005; Simmons et al. 2005). In our results type IV trichomes are present on the most resistant $S$. galapagense accession. Also $S$. habrochaites and S. habrochaites f. glabratum had high densities of type IV and VI trichomes (Eigenbrode and Trumble 1993; Simmons and Gurr 2005).

From our results it is clear that the most resistant and not preferred tomato accessions had a high density of glandular type IV trichomes. Other researchers also reported that the presence of this trichome type highly correlated with resistance to whiteflies and other pests (Dimock and Kennedy 1983; Channarayappa et al. 1992; Snyder et al. 1998; Muigai et al. 2003). Although glandular trichomes seem to play an important role in whitefly resistance, it is actually the compounds within the trichomes that are decisive. For instance, S. habrochaites LA 1777 and LA 1033, have a similar density of type IV trichomes, but they differ in resistance to Helicoverpa zea and Spodoptera exigua and in the constitution of trichome exudates (Frelichowski and Juvik 2001). Examples of such exudates are methylketones such as 2-tridecanone and 2-undecanone which are present at high concentrations in type IV and VI of trichomes and are believed to have an insecticidal effect on several arthropods (Lin et al. 1987; Kashyap et al. 1991; McDowell et al. 2011). Glandular trichomes can also produce zingiberene and sesquiterpene compounds which play role as repellence (Maluf et al. 2001; Bleeker et al. 2009; Kang et al. 2010). Different compounds were identified in S. pennellii and S. pimpinellifolium type IV trichomes. Here, the type IV trichomes contain a high amount of acyl-sugars which make the trichomes sticky (Liedl et al. 1995; Mutschler et al. 1996; Fancelli et al. 2005; Rodriguez-Lopez et al. 2011). Importance of the trichome content is also shown by the fact that the metabolite content of different types of trichomes within an accession/species is more similar than the same type of trichome from different accessions/species of tomato (McDowell et al. 2011).

In contrast to glandular trichomes, non-glandular trichomes, especially type $\mathrm{V}$, are not involved in pest resistance. Whiteflies prefer hairy leaf (Toscano et al. 2002). Non-glandular trichomes provide also a more suitable microclimate for oviposition and protects the eggs and larvae from their enemies (Butter and Vir 1989). A glandular trichome-based resistance mechanism is not the only mechanism in tomato to get whitefly resistance. Whitefly resistance was also found in accessions without glandular trichomes such as in $S$. arcanum CGN14355 and CGN15392, and S. glandulosum CGN14358. Other mechanisms such as leafsurface hardness and cuticle thickness or mesophylicleaf compounds may play a role in the whitefly resistance mechanism as well. Thick cuticles cannot be pierced by the whitefly's stylet (Janssen et al. 1989).

\section{Conclusions}

Correlations of parameters within and between freechoice and no-choice tests show that antibiosis is the major factor for whitefly resistance in tomato accessions. Leaf disc tests are an alternative in vitro method that can be used for whitefly resistance screening. Whitefly resistance level of tomato accessions varied and can change over time. Solanum galapagense PRI95004/PY-8027, which is closely related to commercial tomato, is highly resistant to whitefly over time. Some other accessions from $S$. habrochaites $\mathrm{f}$. glabratum, S. pimpinellifolium, S. arcanum and $S$. glandulosum showed partial resistance. These accessions are potential sources for resistance factor(s), which may be exploited in breeding programs in tomato aimed at whitefly resistance.

Acknowledgments This project was financially supported by Royal Netherlands Academy of Arts and Sciences-KNAW 
(High Quality Solanaceous Vegetables by Exploration of Natural Biodiversity; INDOSOL, 05-PP-21) and SenterNovem grant SOM071010. We are grateful to Leon Westerd (Laboratory of Entomology, Wageningen University, The Netherlands) and Prof. Sri Hendrastuti Hidayat (Bogor Agricultural University, Indonesia) for providing the nonviruliferous B. tabaci for screenings in The Netherlands and Indonesia. We are also grateful to Greet Steenhuis-Broers for her skillful involvement in this research and Dr. Roeland Voorrips for advise on statistical matters.

Open Access This article is distributed under the terms of the Creative Commons Attribution License which permits any use, distribution, and reproduction in any medium, provided the original author(s) and the source are credited.

\section{References}

Baldin ELL, Beneduzzi RA (2010) Characterization of antibiosis and antixenosis to the whitefly silverleaf Bemisia tabaci B biotype (Hemiptera: Aleyrodidae) in several squash varieties. J Pest Sci 83(3):221-227. doi: 10.1007/s10340-010-0289-2

Baldin ELL, Vendramim JD, Lourencao AL (2005) Resistance of tomato genotypes to the whitefly Bemisia tabaci (Gennadius) biotype B (Hemiptera: Aleyrodidae). Neotrop Entomol 34(3):435-441

Bas N, Mollema C, Lindhout P (1992) Resistance in Lycopersicon hirsutum $\mathrm{f}$. glabratum to the glasshouse whitefly (Trialeurodes vaporariorum) increases with plant age. Euphytica 64(october):189-195

Bleeker PM, Diergaarde PJ, Ament K, Guerra J, Weidner M, Schutz S, de Both MT, Haring MA, Schuurink RC (2009) The role of specific tomato volatiles in tomato-whitefly interaction. Plant Physiol 151(2):925-935

Blua MJ, Toscano NC (1994) Bemisia argentifolii (Homoptera: Aleyrodidae) development and honeydew production as a function of cotton nitrogen status. Environ Entomol 23(2):316-321

Broekgaarden C, Poelman EH, Steenhuis G, Voorrips RE, Dicke M, Vosman B (2007) Genotypic variation in genome-wide transcription profiles induced by insect feeding: Brassica oleracea-Pieris rapae interactions. BMC Genomics 8:239

Broekgaarden C, Poelman EH, Voorrips RE, Dicke M, Vosman B (2010) Intraspecific variation in herbivore community composition and transcriptional profiles in field-grown Brassica oleracea cultivars. J Exp Bot 61(3):807-819. doi: 10.1093/Jxb/Erp347

Broekgaarden C, Snoeren TAL, Dicke M, Vosman B (2011) Exploiting natural variation to identify insect-resistance genes. Plant Biotech J . doi:10.1111/j.1467-7652.2011. 00635.x

Butter NS, Vir BK (1989) Morphological basis of resistance in cotton to the whitefly Bemisia tabaci. Phytoparasitica 17(4):251-261

Byrne DN, Miller WB (1990) Carbohydrate and amino acid composition of phloem sap and honeydew produced by Bemisia tabaci. J Insect Physiol 36(6):433-439
Channarayappa Shivashankar G, Muniyappa V, Frist RH (1992) Resistance of Lycopersicon species to Bemisia tabaci, a tomato leaf curl virus vector. Can J Bot 70(11):2184-2192

Chermenskaya TD, Petrova MO, Savelieva EI (2009) Laboratory and field evaluation of biological active substances of plant origin against greenhouse whitefly, Trialeurodes vaporariorum Westw (Homoptera: Aleyrodidae). Arch Phytopathol Plant Prot 42:9(9):864-873

Dimock MB, Kennedy GG (1983) The role of glandular trichomes in the resistance of Lycopersicon hirsutum f. glabratum to Heliothis zea. Entomol Exp Appl 33(3):263-268

Eigenbrode SD, Trumble JT (1993) Antibiosis to beet armyworm (Spodoptera exigua) in Lycopersicon accessions. HortScience 28(9):932-934

Fancelli M, Vendramim JD (2002) Development of Bemisia tabaci (Gennadius, 1889) biotype B on Lycopersicon spp. genotypes. Scientia Agricola 59:665-669

Fancelli M, Vendramim JD, Frighetto RTS, Lourencao AL (2005) Glandular exudate of tomato genotypes and development of B. tabaci (Genn.) (Sternorryncha: Aleyrodidae) biotype B. Neotrop Entomol 34(4):659-665

Filho JPL, Paiva EAS (2006) The effects of sooty mold on photosynthesis and meshophyll structure of mahagony (Swietenia macrophylla) King., Meliaceae., Bragantia, Campinas 65(1):11-17

Frelichowski JE, Juvik JA (2001) Sesquiterpene carboxylic acids from a wild tomato species affect larval feeding behavior and survival of Helicoverpa zea and Spodoptera exigua (Lepidoptera: Noctuidae). J Econ Entomol 94(5):1249-1259

Frelichowski JEJ, Juvik JA (2005) Inheritance of sesquiterpene carboxylic acid synthesis in crosses of Lycopersicon hirsutum with insect-susceptible tomatoes. Plant Breeding 124:277-281

Gurr GM, McGrath D (2001) Effect of plant variety, plant age and photoperiod on glandular pubescence and host-plant resistance to potato moth (Phthorimaea operculella) in Lycopersicon spp. Ann Appl Biol 138(2):221-230

Gusmao MR, Picanco MC, Zanuncio JC, Silva DJH, Barrigossi JAF (2005) Standardised sampling plan for Bemisia tabaci (Homoptera : Aleyrodidae) in outdoor tomatoes. Sci Hortic-Amsterdam 103(4):403-412

Hirano K, Budiyanto E, Swastika N, Fujii K (1995) Population dynamics of the whitefly, Bemisia tabaci (Gennadius) (Homoptera: Aleyrodidae), in Java, Indonesia, with special reference to spatiotemporal changes in the quantity of food resources. Ecol Res 10(1):75-85

Hogenboom NG (1972) Breaking breeding barriers in Lycopersicon. 1. Genus Lycopersicon, its breeding barriers and importance of breaking these barriers. Euphytica 21(2):221-227

Horowitz AR (1986) Population dynamics of Bemisia tabaci (Gennadius) with special emphasis on cotton fields. Agric Ecosyst Environ 17(1-2):37-47

Janssen JAM, Tjallingii WF, van Lenteren JC (1989) Electrical recording and ultrastructure of stylet penetration by the greenhouse whitefly. Entomol Exp Appl 52(1):69-81

Kang JH, Shi F, Jones AD, Marks MD, Howe GA (2010) Distortion of trichome morphology by the hairless mutation of tomato affects leaf surface chemistry. J Exp Bot 61(4):1053-1064. doi:10.1093/Jxb/Erp370 
Kashyap RK, Kennedy GG, Farrar RR (1991) Mortality and inhibition of Helicoverpa zea egg parasitism rates by Trichogramma in relation to trichome methyl ketonemediated insect resistance of Lycopersicon hirsutum $\mathrm{f}$. glabratum, accession PI134417. J Chem Ecol 17(12):2381-2395

Lawson DM, Lunde CF, Mutschler MA (1997) Marker-assisted transfer of acylsugar-mediated pest resistance from the wild tomato, Lycopersicon pennellii, to the cultivated tomato Lycopersicon esculentum. Mol Breeding 3(4):307-317

Liedl BE, Lawson DM, White KK, Shapiro JA, Cohen DE, Carson WG, Trumble JT, Mutschler MA (1995) Acylsugars of wild tomato Lycopersicon pennellii alters settling and reduces oviposition of Bemisia argentifolii (Homoptera, Aleyrodidae). J Econ Entomol 88(3):742-748

Lin SYH, Trumble JT, Kumamoto J (1987) Activity of volatile compounds in glandular trichomes of Lycopersicon species against 2 Insect herbivores. J Chem Ecol 13(4):837-850

Luckwill LC (1943) The genus Lycopersicon: an historical, biological, and taxonomic survey of wild and cultivated tomatoes. Aberdeen Univ Study 120:1-44

Maharijaya A, Vosman B, Steenhuis-Broers G, Harpenas A, Purwito A, Visser RGF, Voorrips RE (2011) Screening of pepper accessions for resistance against two thrips species (Frankliniella occidentalis and Thrips parvispinus). Euphytica 177:401-410

Maliepaard C, Bas N, van Heusden S, Kos J, Pet G, Verkerk R, Vrielink R, Zabel P, Lindhout P (1995) Mapping of QTLs for glandular trichome densities and Trialeurodes vaporariorum (greenhouse whitefly) resistance in an F2 from Lycopersicon esculentum $\times$ Lycopersicon hirsutum $\mathrm{f}$. glabratum. Heredity 75:425-433

Maluf WR, Campos GA, Cardoso MD (2001) Relationships between trichome types and spider mite (Tetranychus evansi) repellence in tomatoes with respect to foliar zingiberene contents. Euphytica 121(1):73-80

Maruthi MN, Muniyappa V, Green SK, Colvin J, Hanson P (2003) Resistance of tomato and sweet-pepper genotypes to tomato leaf curl Bangalore virus and its vector Bemisia tabaci. Int J Pest Manage 49(4):297-303

McAuslane HJ (1996) Influence of leaf pubescence on ovipositional preference of Bemisia argentifolii (Homoptera: Aleyrodidae) on soybean. Environ Entomol 25(4):834-841

McCollum TG, Stoffella PJ, Powell CA, Cantliffe DJ, HanifKhan S (2004) Effects of silverleaf whitefly feeding on tomato fruit ripening. Postharvest Biology and Technology 31(2):183-190

McDowell ET, Kapteyn J, Schmidt A, Li C, Kang JH, Descour A, Shi F, Larson M, Schilmiller A, An LL, Jones AD, Pichersky E, Soderlund CA, Gang DR (2011) Comparative functional genomic analysis of solanum glandular trichome types. Plant Physiol 155(1):524-539. doi: 10.1104/pp.110.167114

Momotaz A, Scott JW, Schuster DJ (2010) Identification of quantitative trait loci conferring resistance to Bemisia tabaci in an F2 population of Solanum lycopersicum $\times S$. habrochaites accession LA1777. J Am Soc Hortic Sci 135(2):134-142

Morales FJ (2007) Tropical whitefly IPM project. Adv Virus Res 69:249-311
Morales FJ, Jones PG (2004) The ecology and epidemiology of whitefly-transmitted viruses in Latin America. Virus Res 100(1):57-65

Muigai SG, Schuster DJ, Snyder JC, Scott JW, Bassett MJ, McAuslane HJ (2002) Mechanisms of resistance in Lycopersicon germplasm to the whitefly Bemisia argentifolii. Phytoparasitica 30(4):347-360

Muigai SG, Bassett MJ, Schuster DJ, Scott JW (2003) Greenhouse and field screening of wild Lycopersicon germplasm for resistance to the whitefly Bemisia argentifolii. Phytoparasitica 31(1):27-38

Mutschler MA, Doerge RW, Liu SC, Kuai JP, Liedl BE, Shapiro JA (1996) QTL analysis of pest resistance in the wild tomato Lycopersicon pennellii: QTLs controlling acylsugar level and composition. Theor Appl Genet 92(6):709-718

Nomikou M, Janssen A, Sabelis MW (2003) Herbivore host plant selection: whitefly learns to avoid host plants that harbour predators of her offspring. Oecologia 136(3):484-488

Perralta IE, Spooner DM, Knapp S (2008) Taxonomy of wild tomatoes and their relatives (Solanum sect. Lycopersicoides, sect. Juglandifolium, sect Lycopersicon; Solanaceae. Syst Bot Monogr 84:1-186

Rodriguez-Lopez MJ, Garzo E, Bonani JP, Fereres A, Fernandez-Munoz R, Moriones E (2011) Whitefly resistance traits derived from the wild tomato Solanum pimpinellifolium affect the preference and feeding behavior of Bemisia tabaci and reduce the spread of tomato yellow leaf curl virus. Phytopathology 101(10):1191-1201

Romanow LR, Deponti OMB, Mollema C (1991) Resistance in tomato to the greenhouse whitefly-analysis of population dynamics. Entomol Exp Appl 60(3):247-259

Schuster DJ (1977) Effect of tomato cultivars on insect damage and chemical control. Fla Entomol 60(3):227-232

Schuster DJ, Mueller TF, Kring JB, Price JF (1990) Relationship of the sweet-potato whitefly to a new tomato fruit disorder in Florida. HortScience 25:1618-1620

Simmons AT, Gurr GM (2005) Trichomes of Lycopersicon species and their hybrids: effects on pests and natural enemies. Agr Forest Entomol 7(4):265-276

Simmons AT, McGrath D, Gurr GM (2005) Trichome characteristics of F1 Lycopersicon esculentum $\times$ L. cheesmanii $\mathrm{f}$. minor and L. esculentum $\times$ L. pennellii hybrids and effects on Myzus persicae. Euphytica 144(3):313-320. doi: 10.1007/s10681-005-8002-x

Sippell DW, Bindra OS, Khalifa H (1987) Resistance to whitefly (Bemisia tabaci) in cotton (Gossypium hirsutum) in the Sudan. Crop Protect 6(3):171-178

Snyder JC, Simmons AM, Thacker RR (1998) Attractancy and ovipositional response of adult Bemisia argentifolii (Homoptera: Aleyrodidae) to type IV trichome density on leaves of Lycopersicon hirsutum grown in three day-length regimes. J Entomol Sci 33(3):270-281

Toscano LC, Boiça JAL, Maruyama WI (2002) Nonpreference of whitefly for oviposition in tomato genotypes. Sci Agricola 59:677-681

van Giessen WA, Mollema C, Elsey KD (1995) Design and use of a simulation model to evaluate germplasm for antibiotic resistance to the greenhouse whitefly (Trialeurodes vaporariorum) and the sweetpotato whitefly (Bemisia tabaci). Entomol Exp Appl 76:271-286 
van Lenteren JC, Noldus LPPJ (1990) Whitefly-plant relationships: behavioural and ecological aspects. In: Gerling D (ed) Whiteflies: their bionomics pest status and management. Intercept Ltd, Andover,pp 47-89
Wilkens RT, Shea GO, Halbreich S, Stamp NE (1996) Resource availability and the trichome defenses of tomato plants. Oecologia 106(2):181-191 